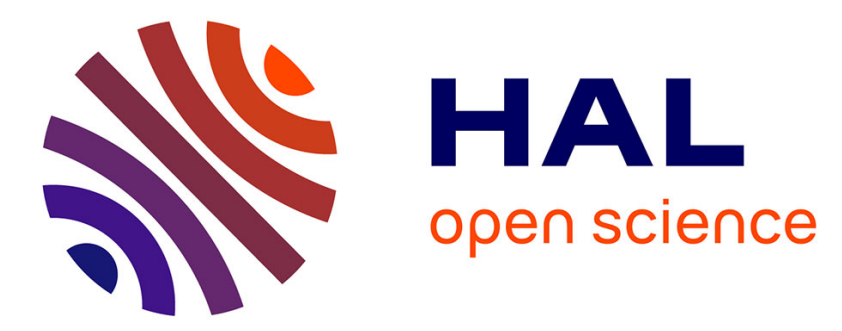

\title{
Fluoroalkyl Amino Reagents for the Introduction of the Fluoro(trifluoromethoxy)methyl Group onto Arenes and Heterocycles
}

Etienne Schmitt, Sebastien Bouvet, Bruce Pegot, Armen Panossian, Jean-Pierre Vors, Sergii Pazenok, Emmanuel Magnier, Frédéric R. Leroux

\section{To cite this version:}

Etienne Schmitt, Sebastien Bouvet, Bruce Pegot, Armen Panossian, Jean-Pierre Vors, et al.. Fluoroalkyl Amino Reagents for the Introduction of the Fluoro(trifluoromethoxy)methyl Group onto Arenes and Heterocycles. Organic Letters, 2017, 19 (18), pp.4960-4963. 10.1021/acs.orglett.7b02444 . hal-02105321

\section{HAL Id: hal-02105321 \\ https://hal.science/hal-02105321}

Submitted on 14 Dec 2021

HAL is a multi-disciplinary open access archive for the deposit and dissemination of scientific research documents, whether they are published or not. The documents may come from teaching and research institutions in France or abroad, or from public or private research centers.
L'archive ouverte pluridisciplinaire HAL, est destinée au dépôt et à la diffusion de documents scientifiques de niveau recherche, publiés ou non, émanant des établissements d'enseignement et de recherche français ou étrangers, des laboratoires publics ou privés. 


\title{
A Fluoroalkyl Amino Reagent for the Introduction of the Fluoro(trifluoromethoxy)methyl Group Onto Arenes and Heterocy- cles
}

\author{
Etienne Schmitt, ${ }^{\dagger}$ Sébastien Bouvet, ${ }^{\#}$ Bruce Pégot, ${ }^{\#}$ Armen Panossian, ${ }^{\dagger}$ Jean-Pierre Vors ${ }^{\ddagger}$ Sergii \\ Pazenok, ${ }^{\S}$ Emmanuel Magnier, ${ }^{\#, *}$ and Frédéric R. Leroux ${ }^{\dagger} * *$ \\ ${ }^{\dagger}$ University of Strasbourg, CNRS, LCM UMR 7509, 25 Rue Becquerel, 67000 Strasbourg, France. E. Schmitt, Dr. A. \\ Panossian, Dr. F. R. Leroux \\ *Bayer S.A.S., 14 Impasse Pierre Baizet, BP99163, 69263 Lyon CEDEX09. Dr. J.-P. Vors \\ ${ }^{\S}$ Bayer CropScience AG, Alfred-Nobel-Strasse 50, 40789 Monheim, Germany. Dr. S. Pazenok \\ "Institut Lavoisier de Versailles, UMR CNRS 8180, Université de Versailles St-Quentin-Yvelines, 45 avenue des Etats-Unis, \\ 78035 Versailles Cedex, France. S. Bouvet, Dr. B. Pégot, Dr. E. Magnier
}

Supporting Information Placeholder

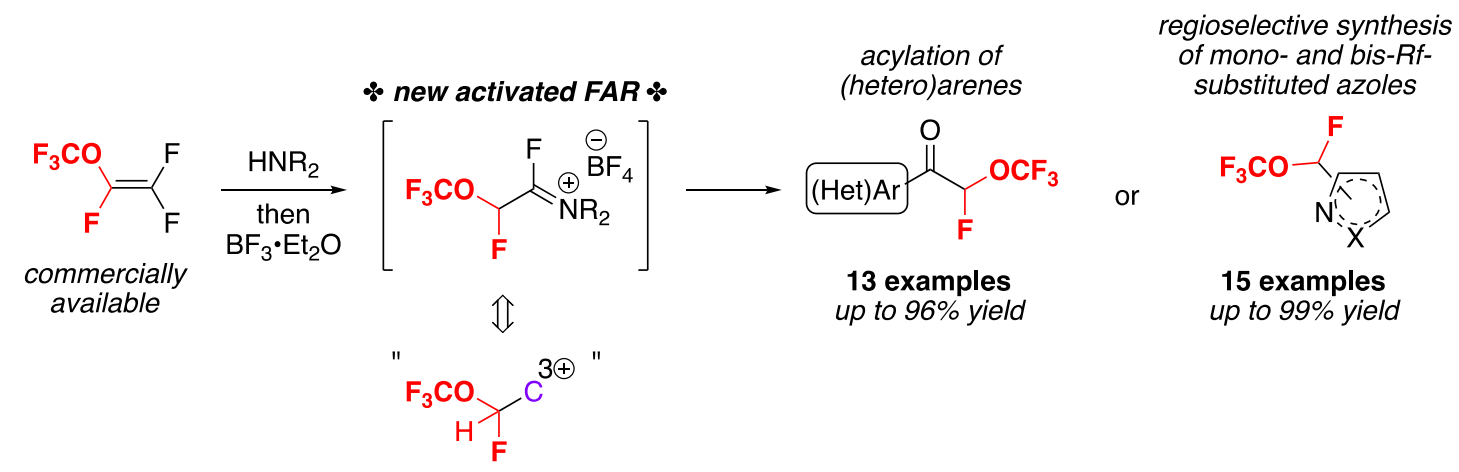

ABSTRACT: Fluoroalkyl amino reagents 1a and 2a have been developed from commercially available trifluoromethyl
trifluorovinyl ether via a hydroamination reaction with diethylamine or dimethylamine. These reagents can be activated by treat-
ment with a Lewis acid, and subsequently used as a mono- or di-electrophile for the introduction of the
fluoro(trifluoromethoxy)methyl group, either in Vilsmeier-type acylations of aromatic substrates, in the synthesis of fluorinated
pyrazoles from CH-acidic substrates or in the synthesis of bis-fluorinated pyrazoles, all being important building blocks for
medicinal
and

Organofluorine chemistry has achieved a key role in the discovery of new bioactive molecules in medicinal or agricultural research, as well as in materials research. ${ }^{1}$ Over past decades, considerable effort has been put into the preparation of $\mathrm{F}$ - and $\mathrm{CF}_{3}$-containing compounds, which, as a result, are now prevalent. More recently, remarkable work has been focused on the introduction of highly potent emergent fluorinated substituents, such as the difluoromethyl or trifluoromethoxy groups $\left(-\mathrm{CHF}_{2}\right.$ and $\left.-\mathrm{OCF}_{3}\right) .{ }^{1 \mathrm{e}, 2}$ The difluoromethyl group, for example, is of great importance as it can act as a more lipophilic isostere of carbinol, thiol, hydroxamic acid, or amide groups. ${ }^{1 \mathrm{~h}, \mathrm{i}, 3}$ Consequently, it has been intensively studied in the design of various pharmaceuticals and agrochemicals. Another highly attractive substituent is the trifluoromethoxy group $\left(-\mathrm{OCF}_{3}\right)$ due to its unique structural and electronic properties. ${ }^{4}$

However, the search for other fluorinated substituents, with diverse physicochemical and biological properties, continues.
Moreover, from an industrial perspective, additional aspects like accessibility and cost of raw materials, waste, safety, scalability, etc. are crucial in the development of synthetic strategies.

Recently, we demonstrated how under-exploited Fluoroalkyl Amino Reagents (FARs) ${ }^{5}$ can be used extensively to facilitate the introduction of various fluoroalkyl groups into (hetero)aromatics. FARs, prepared by hydroamination of bulk fluoro-olefins (which are cheap and available in large scale), could be converted into their corresponding fluoro-iminium salts after Lewis acid activation. These Vilsmeier-type iminium salts revealed high electrophilicity and extended compatibility with many substrates, and proved to be efficient fluoroacylating reagents, as well as remarkable fluoroalkylmethine equivalents for the construction of fluoroalkylated heterocycles (Scheme 1, top). ${ }^{6}$ This method has found use in the industrial production of key intermediates of agrochemical ingredients. 
Thus, existing FARs (see Scheme 1: 1,1,2,2-tetrafluoro$N, N$-dimethylethan-1-amine (TFEDMA, Petrov reagent), ${ }^{7}$ $N, N$-diethyl-2-chloro-1,1,2-trifluoroethan-1-amine (Yarovenko reagent), ${ }^{8}$ and $N, N$-diethyl-1,1,2,3,3,3-hexa-fluoropropan-1amine (Ishikawa reagent) ${ }^{9}$ ) have enabled the introduction of highly challenging - CHFX fluoroalkyl motifs, including the $\mathrm{CHF}_{2},-\mathrm{CHFCl}$ and $-\mathrm{CHFCF}_{3}$ groups, the last two being difficult to access by conventional methods.

Building on this work it was clear that many advances in the field of FARs and fluoroalkyl-(hetero)aromatics remain untapped. The search for other-CHFX groups with promising properties and new aspects of the powerful chemistry of FARs recently prompted us to develop a new FAR bearing the $\mathrm{OCF}_{3}$ moiety. Maslennikov et al. described the synthesis of such a reagent, but unfortunately did not exploit it. ${ }^{[32]}$

Scheme 1. Application of our newly developed FAR in the preparation of high value building blocks for medicinal and agrochemical research.
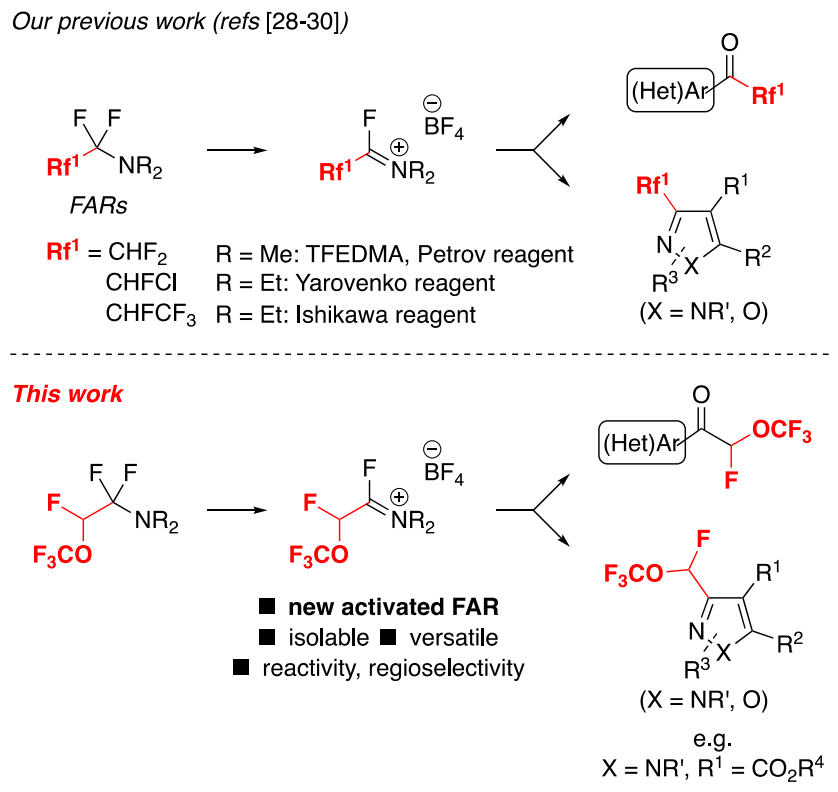

Following preliminary results towards this aim, ${ }^{[30]}$ we detail herein the development of this new FAR, enabling the introduction of the $-\mathrm{CH}(\mathrm{F}) \mathrm{OCF}_{3}$ motif into various substrates. Both the preparation and the reactivity of this new FAR were evaluated and optimized. The acylation of electron-rich arenes was demonstrated, and the synthesis of $\mathrm{CH}(\mathrm{F}) \mathrm{OCF}_{3}$-containing $N$ based heterocycles (pyrazoles, isoxazoles) could also be performed efficiently.

As mentioned above, the hydroamination of perfluorinated alkenes with secondary amines affords FARs. However, potential elimination of HF via the highly acidic $\beta$-proton can lead to the corresponding deactivated perfluorinated enamine. While the Petrov reagent (TFEDMA) is stable under inert atmosphere, the $\mathrm{N}, \mathrm{N}$-dimethyl versions of Yarovenko and Ishikawa reagents are unstable and this elimination occurs even at low temperature. ${ }^{9-10}$ The commercially available $N, N$ diethyl analogues are quite stable upon storage (despite a lower purity) but are less reactive after activation by a Lewis acid. To develop the targeted new FAR, initial work focused on the $N, N$-diethyl substituent since it was anticipated that elimination would be suppressed. Compound 1a was readily prepared by addition of trifluoromethyl trifluorovinyl ether by to neat diethylamine at room temperature in a sealed system
(Scheme 2). This in-situ formed FAR was taken up in DCM and further activated with boron trifluoride etherate, providing the activated FAR 1b. Its structure was indirectly proven after hydrolysis and the isolation (in $71 \%$ global yield) of $\mathrm{N}, \mathrm{N}$ diethylacetamide 1c. A multi-stage reaction -i) FAR preparation, ii) activation by Lewis acid, iii) Friedel-Crafts reactionwas then performed using 1-(dimethylamino)naphthalene as a model substrate (Scheme 2) . Whilst it is a compromise, we found that 5 equiv of trifluoromethyl trifluorovinyl ether afforded an acceptable $72 \%$ yield of compound $\mathbf{3 b}$ (Scheme 2).

Scheme 2. Synthesis of activated FAR 1b (Method A). Optimization of the ratio of gas introduced using $1-\mathrm{NMe}_{2}$ naphthalene as model substrate (bottom).
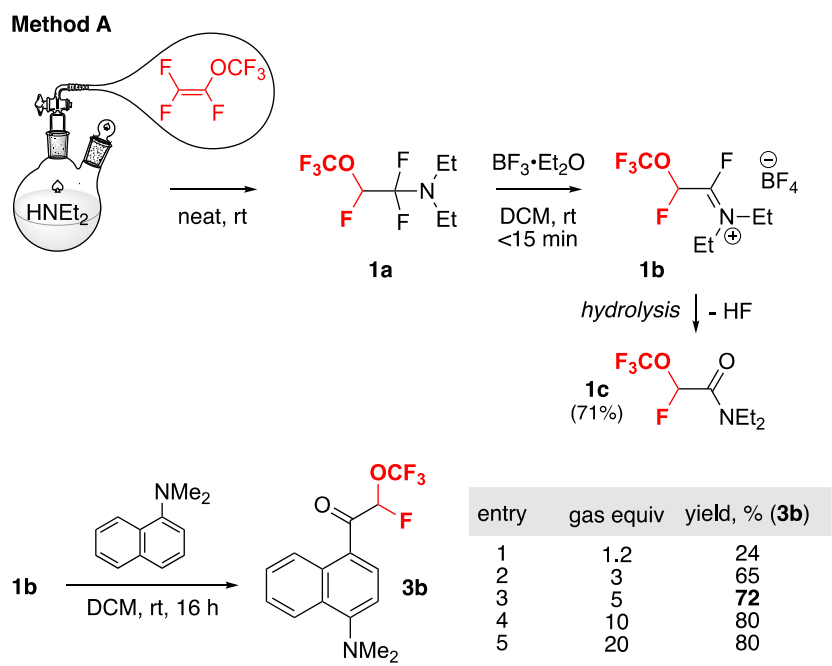

The substrate scope was investigated using similar conditions, whereby a variety of electron-rich aromatic substrates could be acylated (Scheme 3). N,N-Dimethylaniline and 1(dimethylamino)naphthalene smoothly reacted to give rise to compounds 3a and $\mathbf{3 b}$ in high yield. Diversely substituted indoles were similarly acylated providing compounds $\mathbf{4 a - h}$ in modest to high yields. The presence of a nitro-substituent decreased the yield (entry 3, Scheme 3) whilst an amino group provided a product of bis-addition of $\mathbf{1 b}$ with an interesting acetimidamide moiety (4h) in line with Maslennikov's result with aniline. ${ }^{11}$ Pyrroles also reacted with acceptable to good yields (5a-c). Less electron-rich (hetero)aromatic nucleophiles only led to starting material.

In order to enhance the reactivity of the new FAR, we developed an alternative method providing efficiently the $N, N$ dimethyl analogue of 1a (Scheme 4). Trifluoromethyl trifluorovinyl ether was liquefied in a sealed system under inert atmosphere at $-78{ }^{\circ} \mathrm{C}$ before a solution of dimethylamine in THF was added. The hydroamination reaction occurred after the dry-ice/acetone bath was replaced by a water bath; subsequent slow addition of boron trifluoride provided the activated FAR 2b (Scheme 4). Addition of MeCN allowed the direct use of the activated FAR in solution. Alternately, it was possible to precipitate the iminium salt using an excess of DCM, and upon removal of the supernatant, one can determine the exact amount of $\mathbf{2 b}$ formed for use in the next stage. 
Scheme 3. Substrate scope for the acylation of (hetero)aromatic substrates using the activated $N, N$-diethyl FAR $1 b$.
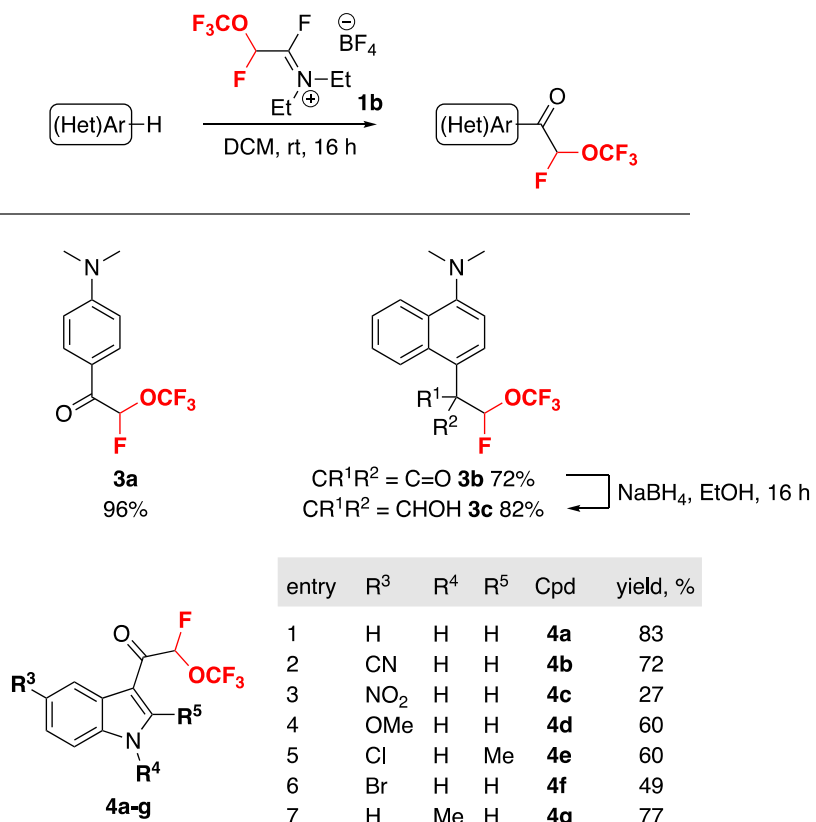

1
2
3
4
5
6
7
8

$\begin{array}{lllll}\mathrm{H} & \mathrm{H} & \mathrm{H} & \mathbf{4 a} & 83 \\ \mathrm{CN} & \mathrm{H} & \mathrm{H} & \mathbf{4 b} & 72 \\ \mathrm{NO}_{2} & \mathrm{H} & \mathrm{H} & \mathbf{4 c} & 27 \\ \mathrm{OMe} & \mathrm{H} & \mathrm{H} & \mathbf{4 d} & 60 \\ \mathrm{Cl} & \mathrm{H} & \mathrm{Me} & \mathbf{4 e} & 60 \\ \mathrm{Br} & \mathrm{H} & \mathrm{H} & \mathbf{4 f} & 49 \\ \mathrm{H} & \mathrm{Me} & \mathrm{H} & \mathbf{4 g} & 77 \\ \mathrm{NH}_{2} & \mathrm{H} & \mathrm{H} & \mathbf{4 h} & 24\end{array}$<smiles>CCN(CC)C(=Nc1ccc2[nH]cc(C(=O)C(F)OC(F)(F)F)c2c1)C(F)(F)F</smiles><smiles>O=C(OC(F)(F)F)C(F)C(=O)c1ccc[nH]1</smiles><smiles>Cn1ccc(C(=O)C(F)OC(F)(F)F)c1</smiles>

$5 b / 5 c 86 \%(52 / 48)$

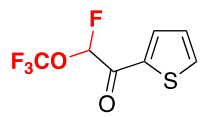

5 d $6 \%$

Scheme 4. Synthesis of the activated $N, N$-dimethyl FAR $\mathbf{2 b}$.

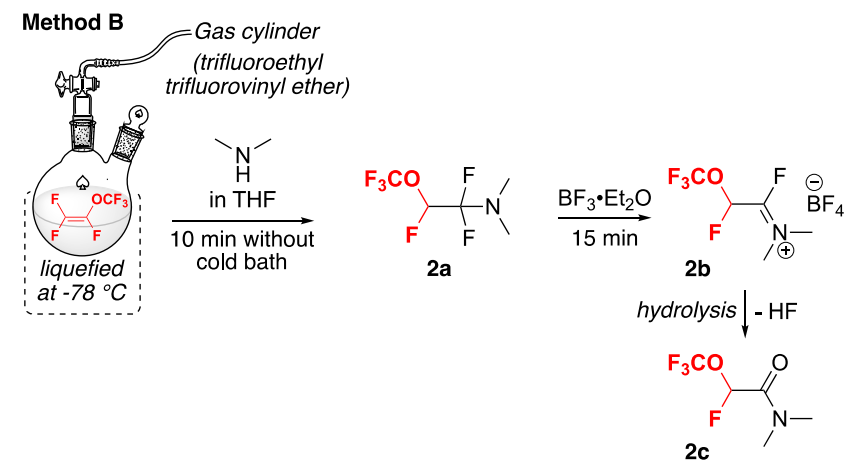

Next, we decided to study the scope of this new reagent in the reaction with $\mathrm{CH}$-acidic compounds like malonitrile and cyanoacetates. When the activated $\mathrm{OCF}_{3}-\mathrm{FAR} \mathbf{2 b}$ was reacted with malonitrile, intermediate 6a could be isolated after deposition of the crude product on alumina and washing with cyclohexane. Subsequent treatment with hydrazines or hydroxylamine provided rapidly and regioselectively the corresponding pyrazoles $\mathbf{7 a - b}$ and isoxazole $\mathbf{7} \mathbf{c}$ in excellent yield (Scheme 5). The use of BOC-hydrazide was the preferred source of the hydrazine moiety, despite the longer reaction time, as it provided an optimal yield of the cyclized compound in the form of the $\mathrm{NH}$-pyrazole $7 \mathbf{a}$ upon spontaneous cleavage of the $N$-BOC group during silica gel chromatography. Intermediate 6b was similarly prepared and used without further purification to provide regioselectively the parent ester $8 \mathbf{a}$ in moderate yield.

Scheme 5. Regioselective preparation of 3-( $\left.\mathrm{CHFOCF}_{3}\right)-5-$ aminopyrazolecarbonitriles and -carboxylates and of the related isoxazoles.
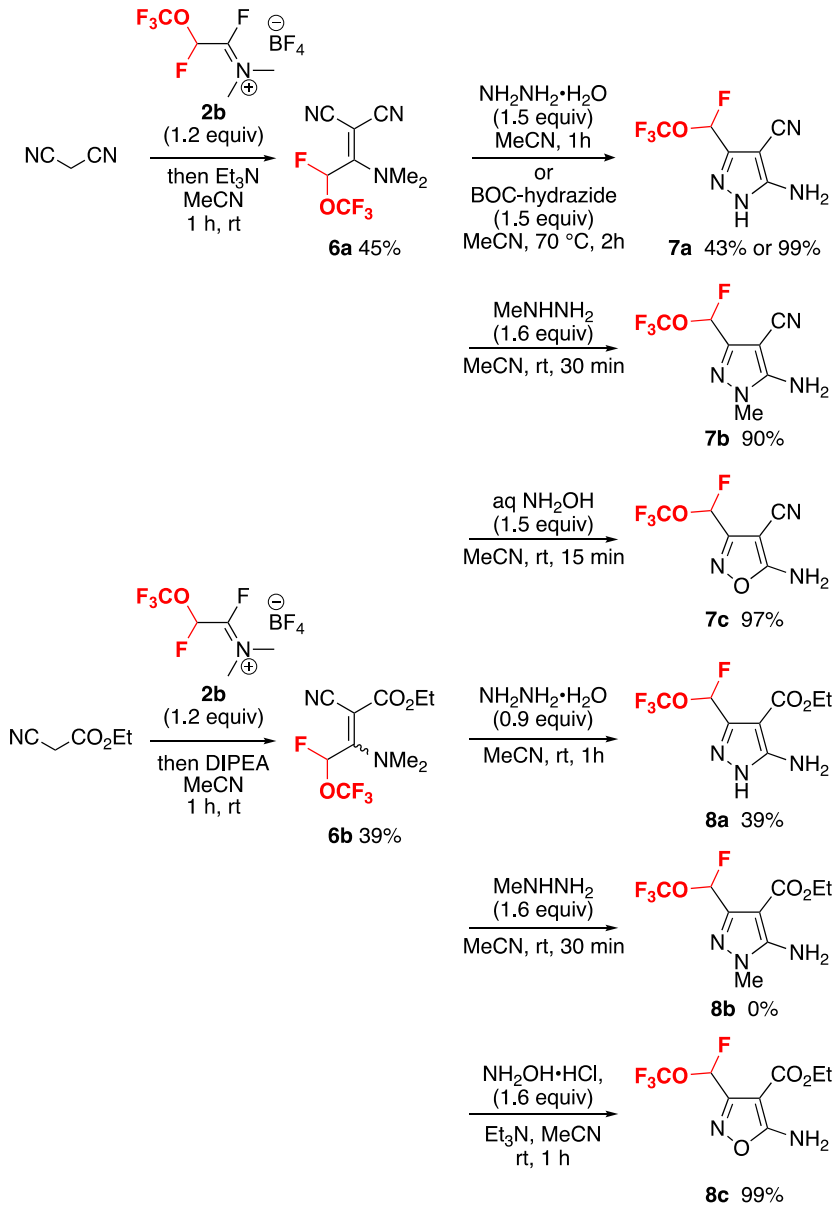

The quantitative synthesis of isoxazole 8c provided single crystals, which confirmed the expected regioselectivity (Figure 1). The activated new FAR $\mathbf{2 b}$ was also used to prepare several analogues (9-11, Scheme 6) of a key intermediate of Bixafen, a modern SDHI fungicide (Bayer CS) currently on the market.

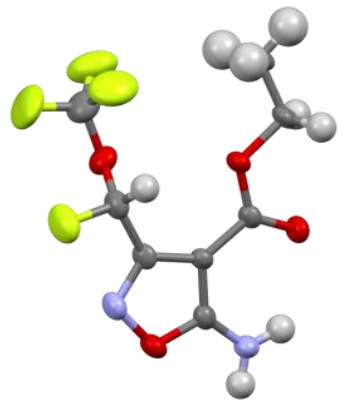

Figure 1. Crystallographic structure of 8c (CCDC 1567305) ellipsoids at the $50 \%$ probability level; 2 molecules per single unit 
cell; the second molecule (enantiomer, under a different conformation) is hidden for clarity.

Scheme 6. Preparation of $\mathrm{OCF}_{3}$-analogues of a key intermediate of Bixafen.
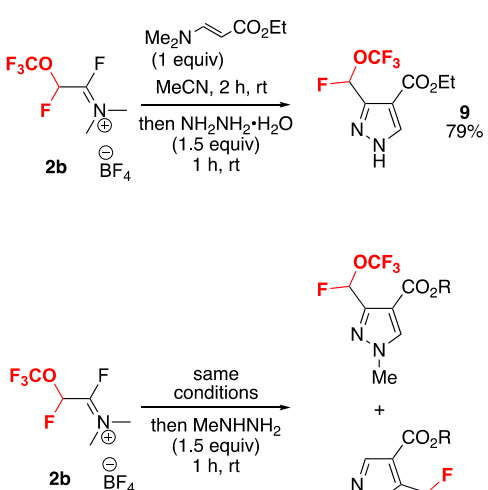

$\mathrm{Me}$

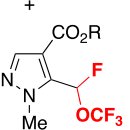

$\begin{aligned} & \begin{array}{l}10 \mathrm{~b} \\ 19 \%\end{array} \\ & \begin{array}{l}\mathbf{1 1 b} \\ >99 \%\end{array}\end{aligned} \quad \mathrm{R}=\mathrm{H} \quad \square \begin{aligned} & 2 \mathrm{~N} \text { aq } \mathrm{NaOH}, \mathrm{EtOH}, \\ & 18 \mathrm{~h}, \mathrm{rt}\end{aligned}$
Furthermore, the new FAR 2a was employed in the preparation of 3,5-bis(fluoroalkyl)- $\mathrm{HH}$-pyrazoles (12a-c, Scheme 7) and in the regioselective preparation of 3,5-bis(fluoroalkyl)NMe-pyrazoles (13a-c and 14a, Scheme 7).

Scheme 7. Regioselective preparation of 3,5bis(fluoroalkyl)pyrazoles bearing the $-\mathrm{CHFOCF}_{3}$ motif.

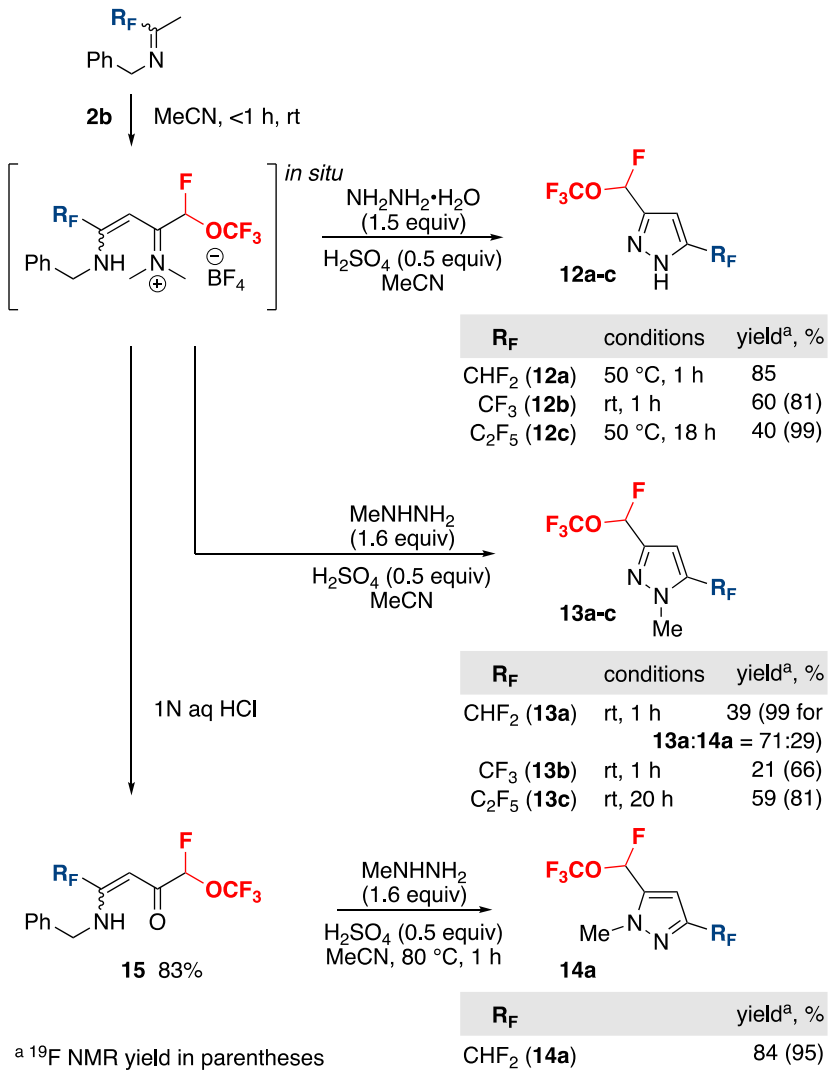

These high-value building blocks were synthesized in excellent yields, using a tunable regioselectivity strategy. We recently reported on the opposed reactivities of in-situ formed vinamidinium species and the corresponding isolated vinamides. ${ }^{6 \mathrm{~b}}$ Hence, vinamide 15, which could be isolated in $83 \%$ yield, was further transformed into the regioisomer 14a (95\%), whereas the alternative regioisomer 13a (99\%), was prepared from the corresponding vinamidinium intermediate (Scheme 7).

In conclusion, we have developed Fluoroalkyl Amino Reagents allowing for the introduction of the unstudied trifluoromethoxy-bearing substituent $-\mathrm{CHFOCF}_{3}$ in aromatics and heteroaromatics. The in-situ formed $N, N$-diethyl analogue could be used to acylate very electron-rich aromatic substrates. The $N, N$-dimethyl analogue was used to prepare a large variety of fluoroalkyl-pyrazoles and isoxazoles. This study further enhances the potential of the use of FARs for the introduction of fluoroalkyl groups.

\section{ASSOCIATED CONTENT}

\section{Supporting Information}

The Supporting Information is available free of charge on the ACS Publications website.

Experimental procedures and compound characterization (PDF), as well as X-ray diffraction crystallography structure for 8c (CCDC 1567305) (CIF).

\section{AUTHOR INFORMATION}

\section{Corresponding Authors}

* E-mail: frederic.leroux@unistra.fr, emmanuel.magnier@uvsq.fr Notes

The authors declare no competing financial interest.

\section{ACKNOWLEDGMENT}

We thank the CNRS (Centre National de la Recherche Scientifique, France), the French Ministry of Research for a grant to S.B. and are very much grateful to Bayer S.A.S. for a $\mathrm{PhD}$ grant to E.S. The French Fluorine Network (GIS Fluor) is also acknowledged.

\section{REFERENCES}

(1) (a) Kirsch, P. Modern Fluoroorganic Chemistry: Synthesis, Reactivity, Applications; Wiley-VCH: Weinheim, Germany, 2013; (b) Muller, K.; Faeh, C.; Diederich, F. Science 2007, 317, 1881; (c) Bégué, J. P.; Bonnet-Delpon, D. Bioorganic and Medicinal Chemistry of Fluorine; Bégué, J. P.; Bonnet-Delpon, D.; Wiley: Hoboken, NJ, 2008; (d) Zhou, Y.; Wang, J.; Gu, Z.; Wang, S.; Zhu, W.; Acena, J. L.; Soloshonok, V. A.; Izawa, K.; Liu, H. Chem. Rev. 2016, 116, 422; (e) Wang, J.; SanchezRosello, M.; Acena, J. L.; del Pozo, C.; Sorochinsky, A. E.; Fustero, S.; Soloshonok, V. A.; Liu, H. Chem. Rev. 2014, 114, 2432; (f) Purser, S.; Moore, P. R.; Swallow, S.; Gouverneur, V. Chem. Soc. Rev. 2008, 37, 320; (g) Gouverneur, V.; Seppelt, K. Chem. Rev. 2015, 115, 563; (h) Meanwell, N. A. J. Med. Chem. 2011, 54, 2529; (i) Gillis, E. P.; Eastman, K. J.; Hill, M. D.; Donnelly, D. J.; Meanwell, N. A. J. Med. Chem. 2015, 58, 8315. (2) (a) Lu, Y.; Liu, C.; Chen, Q.-Y. Curr. Org. Chem. 2015, 19 , 1638; (b) Rong, J.; Ni, C.; Hu, J. Asian J. Org. Chem. 2017, 6, 139.

(3) (a) Erickson, J. A.; McLoughlin, J. I. J. Org. Chem. 1995, 60, 1626; (b) Yerien, D. E.; Barata-Vallejo, S.; Postigo, A. Chem. Eur. J. 2017, DOI:10.1002/chem.201702311; (c) Sessler, C. D.; Rahm, M.; Becker, S.; Goldberg, J. M.; Wang, F.; Lippard, S. J. J. Am. Chem. Soc. 2017, 139, 9325 .

(4) (a) Feng, P.; Lee, K. N.; Lee, J. W.; Zhan, C.; Ngai, M.-Y. Chem. Sci. 2015, 7, 424; (b) Leroux, F. R.; Manteau, B.; Vors, J. P.; Pazenok, S. Beilstein J. Org. Chem. 2008, 4, 13; (c) Toulgoat, F.; Billard, T. Chem 2017, 2, 327; (d) Tlili, A.; Toulgoat, F.; Billard, T. Angew. Chem. Int. Ed. 2016, 55, 11726; (e) Besset, T.; Jubault, P.; Pannecoucke, X.; Poisson, T. Org. Chem. Front. 
2016, 3, 1004; (f) Zriba, R.; Desmarchelier, A.; Cadoret, F.; Bouvet, S.; Barthelemy, A.-L.; Pégot, B.; Diter, P.; Dagousset, G.; Blazejewski, J.-C.; Anselmi, E.; Yagupolskii, Y.; Magnier, E. Molecules 2017, 22, 966; (g) Sokolenko, M. T.; Dronkina, I. M.; Magnier, E.; Yagupolskii, M. L.; Yagupolskii, L. Y.; Zriba, R.; Desmarchelier, A.; Cadoret, F.; Bouvet, S.; Barthelemy, A.-L.; Pégot, B.; Diter, P.; Dagousset, G.; Blazejewski, J.-C.; Anselmi, E.; Yagupolskii, Y.; Magnier, E. Molecules 2017, 22, 804; (h) Kondratov, I. S.; Logvinenko, I. G.; Tolmachova, N. A.; Morev, R. N.; Kliachyna, M. A.; Clausen, F.; Daniliuc, C. G.; Haufe, G. Org. Biomol. Chem. 2017, 15, 672; (i) Liu, J. B.; Chen, C.; Chu, L.; Chen, Z. H.; Xu, X. H.; Qing, F. L. Angew. Chem. Int. Ed. 2015, 54, 11839; (j) Hojczyk, K. N.; Feng, P.; Zhan, C.; Ngai, M.Y. Angew. Chem. Int. Ed. 2014, 53, 14559; (k) Manteau, B.; Genix, P.; Brelot, L.; Vors, J.-P.; Pazenok, S.; Giornal, F.; Leuenberger, C.; Leroux, F. R. Eur. J. Org. Chem. 2010, 6043. (5) (a) Commare, B.; Schmitt, E.; Aribi, F.; Panossian, A.; Vors, J.-P.; Pazenok, S.; Leroux, F. R. Molecules 2017, 22, 977; (b) Petrov, V. A. Adv. Org. Synth. 2006, 2, 269.

(6) (a) Schmitt, E.; Rugeri, B.; Panossian, A.; Vors, J. P.; Pazenok, S.; Leroux, F. R. Org. Lett. 2015, 17, 4510; (b) Schmitt, E.; Panossian, A.; Vors, J. P.; Funke, C.; Lui, N.; Pazenok, S.;
Leroux, F. R. Chem. Eur. J. 2016, 22, 11239; (c) Aribi, F.; Schmitt, E.; Panossian, A.; Vors, J.-P.; Pazenok, S.; Leroux, F. R. Org. Chem. Front. 2016, 3, 1392; (d) Schmitt, E.; Landelle, G.; Vors, J. P.; Lui, N.; Pazenok, S.; Leroux, F. R. Eur. J. Org. Chem. 2015, 6052.

(7) Petrov, V. A.; Swearingen, S.; Hong, W.; Chris Petersen, W. J. Fluorine Chem. 2001, 109, 25.

(8) Yarovenko, N. N.; Raksha, M. A. Zh. Obshch. Khim. 1959, 29, 2159.

(9) Takaoka, A.; Iwakiri, H.; Ishikawa, N. Bull. Chem. Soc. Jpn. 1979, 52, 3377.

(10) (a) Redlich, M. Aldrich ChemFiles 2008, 8.3, 4; (b) Bernd, B. Houben-Weyl Methods of Organic Chemistry; Vol. E 10b/1; 4 ed.; Organo-Fluorine Compounds - Synthesis of Fluorinated Compounds I, Transformations of Fluorinated Compounds; Büchel, K. H.; Falbe, J.; Hagemann, H.; Hanack, M.; Klamann, D.; Kreher, R.; Kropf, H.; Regitz, M.; Schaumann, E.; Georg Thieme, 2014, pp. 100-102.

(11) Maslennikov, I. G.; Eremin, K. I. Russ. J. Gen. Chem. 2011, 81,1741 . 